DOI: 10.20472/AHC.2019.005.006

NOEL PACKARD

University of Auckland, New Zealand

\title{
EXPLOITING THE “COMMUNIST THREAT“, FOR THE PRIVATIZED INTERNET
}

\begin{abstract}
:
Levine's Surveillance Valley reports how the Internet was privatized without public debate or resistance but overlooks decades of neoliberal economic and anti-communist purging history that had chilling effects on public resistance to Internet privatization - that history gap is explored here. How did military-industrial-complex contractors, using neoliberal and Communist threat rational, incentivize Internet development, while lessening the possibility of public interference to Internet privatization? Weber's special-skilled-occupational-status-group-theory is overlaid onto neoliberal economic and military-industrial-complex history to argue occupational-contractor-status-groups, with their monopoly access to early computer technology, fulfilled neoliberal doctrine by creating and protecting private markets for the Internet and exploited Communist threat rational to help clear the privatization path of people who might impede market plans.
\end{abstract}

\section{Keywords:}

Internet, neoliberal, DARPA, Communist Threat, Cold War, national security

JEL Classification: A14, H56, 033 


\section{Introduction}

Much history is written about the creation of the Internet - but how the Internet emerged first as a weapon for surveillance and how it became privatized, is less exalted. Yasha Levine (2018) and Shoshanna Zuboff (2019), offer new insights into Internet history. While Levine laments the lost history of 1960 s student protests against military intelligence $R \& D$ programs, Zuboff advocates mass action to make the government control the Internet today. Levine cites historical facts about how the Internet was privatized without public debate. It appears decades of neoliberal efforts to attack the "Communist threat" and discredit, fire, intimidate and purge the US of New Deal or government planning or Keynesian-minded activists, who might have demanded regulation, control or ownership of the taxpayer-paid-for-Internet infrastructure, needs to be revisited. This study fills in some of that gap in the Internet history, about how the path to Internet privatization, administered through military-industrial-complex contractors with monopoly access to new computer technology, didn't just pave the way to privatization but also "paved over" Keynesian economic ideas and the kinds of people who might challenge its' privatization. It did this using both anti-communist and national security rational and by using the Internet against the kinds of people who might have advocated that the Internet be made a public utility.

The research design is flow of argument that the development and privatization of the Internet was fulfilled by occupational-status-groups of the military-industrial-complex or Pentagon contracted scientists, who were mandated to limit public knowledge of their inventions, under the auspices of National Security. Weber's occupational (specially-skilled) status-group theory is applied to historical facts about neoliberal economics and communist purging Cold War history. Facts are drawn from the works by Mirowski, Jacobsen, Donner, Levine, Leeson, Rohde and others to characterize the social relations of the military-industrial-surveillance-complex and intelligence agencies as a constellation of status-groups, classes and parties, fulfilling the functions of neoliberal doctrine - creating and protecting markets for DARPA's inventions or inversely creating weapons for new markets (Weber 1978, p. 937). Advanced weapons industry fostered a self-styled status occupational-groups that not only produced bombs and surveillance technology like the Internet, $\mathrm{pc}$ and cell phone but also performed the labor of keeping national security secrets and setting examples of correct ways of thinking for the public regarding matters of national defense or national security.

\section{Research Question and Methodology}

How did military-industrial-complex contractors, using neoliberal and Communist threat rational, incentivize Internet development, while lessening the possibility of public interference to Internet privatization? Max Weber's status group theory theoretically frames the argument because the topic entails study of: specially skilled-occupation-groups inside of organizations; highly educated individuals; ideologies; rational; bureaucracy; occupational-groups (vs. parties or classes); status; and the shared context of subjective meaning regarding the communist threat, neoliberal economics, national defense and national security. This study draws on organizational, military, political and rhetorical history from the Cold War era. Weber distinguishes a status group as a selfstyled group of people within an organization, who share a common lifestyle that includes a formal education, empirical training and rational instruction, with corresponding forms of behavior, and hereditary or occupational prestige. Status groups are within an organization in the "sphere of the 
distribution of honor" (Weber, 1978, pp. 306, 938). Rather than producing goods the occupationalstatus-group contractor was enlisted for intelligence and being a bearer of advice in "correct ways of thought" administration and decision making which they programed into the super computers and Internet (Weber 1951/1964, pp. 107-141, 121).

\section{Background History and Case Study}

3.1 Clearing the privatization path of the Communist Threat: the Red Scare to the militaryindustrial-complex

Anti-Communism has a long history in the U.S., associated with episodes such as: The Red Scare; the Second Red Scare and the McCarthy Hearings on Un American Affairs. The Bolshevik Revolution of November 1917 gave American capitalists reasons to fear worker overthrow and nationalization of private capital, particularly since American workers already participated in Communist parties. America's first Red Scare was a time when terrorist actions were blamed on Communists. At the turn of the century US worker parties, like the International Workers of the World (Wobblies) had strong memberships and engaged in radicalism, riots and strikes (Murray 1955, pp. 111-134) like the Seattle General Strike - which the press sensationalized. In response "patriotic societies" active in promoting 100 per cent patriotism during WWI, mobilized against the so-called "Red menace." According to Murray these societies were founded by wealthy businessmen and:

the real motives of the patriotic societies were not always the publicly declared ones since patriotism was definitely tied to the security of private property and more especially to the maintenance of economic conservatism. All patriotic organizations were hostile to organized labor (Murray, 1955, p. 85).

Murray explains that although the membership of the patriotic societies was only about 25,000 their propaganda campaigns were highly effective in promoting the virtues of 100 per cent Americanism as an counterinsurgency method against Bolshevism. Patriotic societies, anti-communist and 100-per cent Americanism dogma, were used to help sever ties between recent immigrants (many who were in the industrial trade unions) and their relationships to Europe for a least two reasons. First to disengage the trade unions from their European inspired roots. Second to make it easier to coerce the US population to support US involvement in a war in Europe. In a Weberian analysis, conservative businessmen and trade unionists are two economic classes with different economic interests to protect (Weber 1978, pp. 928-9). In this case the capitalist class was protecting its interest in dominating labor, while incentivizing the potential for war by exploiting Communist threat rhetoric to undermine the creditability (and employability) of immigrant and trade unions. In short, trade unionists were pressured to disavow any subjective meaning system that wasn't "100 per cent Americanism" or essentially, neoliberalism; which was deemed by American businessmen as patriotic and in the interest of American capitalism. Rockefeller and William Hearst backed patriotic societies. The power Hearst had over the press caused Franklin D Roosevelt (FDR) to take on a vice presidential running mate, John Garner, who did not support FDR's New Deal but did support Hearst's "America First" campaign (Rauchway 2018). 
In $1936 \mathrm{~J}$. Edgar Hoover told President Roosevelt three trade unions were being taken over by communists and would paralyze the country. Hoover exaggerated the communist threat but FDR secretly broadened the FBl's internal security powers and requested general appropriation funding for expanding the FBI. This was done without Congressional approval and created a permanent domestic intelligence structure in the FBI. Hoover immediately created the FBl's Legion Contact Program, which enlisted more than fifty thousand members of the patriotic organizations to clandestinely gather intelligence on suspected subversives (Rosenfeld 2013, p, 21; Theoharis 1985). Here the interests of the FBI merged with the interests of the neoliberal capitalists when the FBI enlisted American Legion patriot society members in 1940. Hoover also began using illegal wiretaps in 1940. FDR unilaterally and secretly issued a directive declaring that a US Supreme Court order that banned wiretapping did not apply to national defense investigations of enemies inside the US. Roosevelt required Hoover get approval from the attorney general for the wiretaps but other than that Hoover wasn't subject to government oversight. In 1942 Hoover began performing unauthorized break-ins of homes and offices suspected of being "subversive." Hoover devised a filing and communication system that both directed and covered-up these unauthorized break-ins (Churchill \& Wall 1990 p. 29-32; Donner 1981, p. 12; Rosenfeld 2013, p. 21; Storrs 2013, pp.184-5). FBI counterinsurgency programs required "numbers" to justify increased funding. Donner observes:

Yet the problem was not to make plausible the threat of revolution But to create a nurturing environment for countersubversion as a force in mainstream politics and to ensure intelligence power and funding. The commitment to identification was a gamble: the credibility won through identification of live subversives would be lost by unimpressive total numbers. Thus the padding of the population of subversives became the most important mission of intelligence assessment... This was a daunting task in view of the initial small number of Party members and the steady decline both in membership and influence beginning with the cold war. The Director's contribution was to end the practice of publicizing membership figures, to insist that the decline was proof of strength, not of weakness, and to warn of armies of secret adherents, "members of the conspiracy" (Donner 1981, p. 14)

The FBI American Legion contact program, which enlisted more than 50,000 civilian American Legion "informational sources" and "confidential informants" helped "pad the numbers" of insurgents and expand FBI man-power, funding and illegal, secret, activities. The American Legion Contact Program enabled the FBI to establish itself as a self-styled, almost autonomous, security agency administered by individuals who operated beyond the law; it also kept the American Legion from starting its' own intelligence service, which would have jeopardized the FBI's market on US domestic national security.

The FBI co-opted "confidential reporters" from the Legion who had "good judgment, employment in important industrial or public utility facilities or who had contacts with conditions in their communities relating to groups of foreign extraction or un-American 
sympathies" (Theoharis 1985, p. 276). The FBI enlisted patriotic Legion society members to become "confidential informants" (although they were considered unpaid "information sources") for anti-communist campaigns. This system of enlisting civilian workers to spy on other civilians shows the early formation of a specially skilled, human-occupation-statusgroup whose function would become largely automated once the Internet was commercialized. In creating the "FBI confidential informant" program the FBI kept the Legion from becoming a competitor security agency, gained a monopoly on the Legions' "sources of information" and used the membership of the program as a Public Relations (RP) venue for the $\mathrm{FBI}$ since the partnership sent the right kind of patriotic message to the public. The end result of these activities, according to Athan Theoharis, was the American Legion Contact program, which began in 1940 and ended in 1966, served an important purpose in creating a "permanent covert expansion of the FBI's nationwide surveillance capabilities through the recruitment of thousands of confidential informants." (Theoharis 1985, p. 282).

Weber argued in The Protestant Ethic and the Spirit of Capitalism (1930/1992), once the Protestants achieved wealth accumulation and created a system of modern capitalism they (and their faith) were no longer needed and capitalism operated mechanically without them or operated like an iron cage, around them (Weber1930/1995, p.181-2). Here the FBI used the American Legion informants to: 1) restrain the Legion from operating its own competing security agency, while 2) expanding the FBI's own "market territory" and helping it establish itself as a near monopoly domestic national security and intelligence agency, at least until 1966, when the Legion contact program was deemed no longer needed and terminated. These traits exemplify Weber's definition of status-groups that help control a monopoly market and it foretells of the kind of contracted-civilian-occupational-skilled-status groups that were recruited later into the military industrial complex.

Weber stated, "Status groups are also created by property classes" which is true for the patriot societies, formed by the capitalists, whose members were enlisted to the FBI (Weber 1978, pp. 306-7). Weber also claims status groups come into being: a) by virtue of a lifestyle (for example 100 per cent Americanism or pro-neoliberalism) and vocation or specially skilled occupational-status (for example, the first computer programmers or pioneering software engineers); b) hereditary status and successful claims to higherranking descent; c) through monopolistic appropriation of political or hierocratic status groups (such as the patriot Legion society being appropriated to the political needs of the $\mathrm{FBI}$ ). In terms of their character, status groups strive for respect (more than for riches or fame) as honorable or in this case 100 percent Americans, with special knowledge and privileges (such as security clearances and academic degrees). Status groups shun hard physical labor, entrepreneurial activity and hard bargaining (Weber 1978, pp. 936-37). They often have their own language or jargon, reward systems (such as the Noble Prize for Economics) and intermarriage is not uncommon. The FBI formed a contact program with the American Legion in 1940 and although Legion agents weren't paid and kept on a temporary basis, the job was part of an occupational-status-group because it was honorable and one had to be a patriotic 100 per cent American to serve. Weber points out that even slaves are part of a status society because basically they do not consume or own what their labor is invested into (Weber 1978, p. 928). For example, contract scientists did 
not own the Internet and American Legion contacts did not always get paid for their service to the FBI.

During the Interwar period between World War I (WWI) and World War II (WWII) pluralism in politics, economics and social welfare approaches flourished in America as people sought ways to mitigate the Depression (Morgan \& Rutherford, 1998). President Roosevelt established "New Deal" employment and other social welfare programs, which were popular among ordinary Americans but capitalists, industrialists and the elite resented government power, planning, regulation and encroachment on what they thought was private business domain. Many businessmen and conservatives shunned FDR's New Deal programs government planning and the "institutional " or Keynesian style economics that promoted planned and regulated economies to avoid economic crisis and promote full employment (Keynes 1964/1953). Conservative businessmen, some of whom funded patriotic societies, such as Macy and Hearst, couched neoliberal economics, while John D. Rockefeller funded the Chicago School (Murray 1955; Rauchway 2018; Van Horn et. al. 2011; Van Overtveldt 2007). Harvey defines neoliberalism in the following way:

Neoliberalism is... a theory of political practices that proposes that human well-being can best be advanced by liberating individual entrepreneurial freedoms and skills within and institutional framework characterized by strong property rights free markets, and free trade. The role of the state is to create and preserve. . . such practices. The state has to guarantee. . quality and integrity of money. . and . . secure private property rights and to guarantee by force if need be, the proper functioning of markets. . . if markets do not exist (in areas such as land, water, education, health care, social security or environmental pollution) then they must be created, , by state action . . . But beyond these tasks the state should not venture. State interventions in markets (once created) must be kept to a bare minimum because according to the theory the state cannot possibly possess enough information to second guess the market signals (prices) and because powerful interest groups will inevitably distort and bias state interventions (particularly in democracies) for their own benefit. (Harvey 2005, p. 2)

Conservatives undermined New Dealers by calling them Communists and propagandized New Deal programs as communistic. They set up investigations where alleged Communists were subjected to public scrutiny and interrogations about their loyalty to America. Senator Joseph McCarthy's Committee on Un American Affairs investigations were conducted against the movie and entertainment industries (Stone \& Kuznick, 2013, pp. 230-235). Those who were identified as Communist were blacklisted and purged from Hollywood (Rosenfeld, 2013). This helped assure popular Hollywood stars and their loyal fan clubs wouldn't agitate for something communistic, like a public utility, regulated hydropower plants or oversight of defense budgets.

Less well know are the Dies Committee investigations that preceded the McCarthy hearings. Susan Brinson's (2004) The Red Scare, Politics, and the Federal 
Communications Commission, 1941-1960 details how Martin Dies, a House of Representative Democrat, along with corporate executives in the broadcasting industries (television and radio) mobilized to undermine Federal Communication Commission (FCC) Chairman Larry Fly's earliest efforts to protect the public interest against unregulated media corporate and monopoly practices. The FCC was formed specifically to deal with the issue of regulating frequency ranges and licensing of radio stations. The Radio Act of 1912 set a precedent for government control over the broadcast industry, but did not give the government ways to enforce the licensed broadcasting. As frequency regulation problems grew a new Radio Act of 1927 was implemented, along with a Federal Radio Commission to enforce it. This Act proved to be successful in regulating what was fast becoming a multimillion-dollar industry - profitable in part because of the government's oversight. Brinson reports:

Five years later, in 1940, those figures escalated to a total of $\$ 166$
million in revenue generated by the radio networks, accomplishments
that could not have been achieved without the enormously successful
Radio Act of 1927 . Indeed, the Radio Act and its guardian Federal
Radio Commission were so effective at repairing and regulating the
radio industry that President Franklin Roosevelt successfully
persuaded Congress to expand the Commission's scope. The
Communications Act of 1934 reconstructed the Federal Radio
Commission and gave it regulatory authority over all forms of
communication including broadcasting, telegraph, and telephone.
Virtually all the operating and licensing requirements contained In the
Radio Act of 1927 were carried over to the 1934 legislation,
especially the public interest requirement (Brinson 2004, p. 9).

This is an example of what successful institutional, Keynesian or New Deal economics looked like in an American context - the government had helped regulate and foster the profitable new media industry, while mandating it be operated with public interest requirements. The government expanded legislation again in 1934 and Larry Fly was appointed Chair of a new Commission in 1939. Brinson writes that "Fly was a New Dealer who made no secret of incorporating New Deal policies into regulation of the broadcasting industry" (2004, p 19) which set Fly and the FCC on a collision course with: the Dies Committee; the powerful television companies and networks; and with the politicians who saw mass media as critical to their campaign and political interests.

Instead of passively allowing the media industry to "guide" the FCC, Fly and the Commission actively pursued New Deal style legislation in the interest of the public. Fly hired Columbia University professor Dr. Goodwin Watson, a social psychologist and authority on propaganda techniques to oversee the Foreign Broadcast Monitoring Service (FBMS). The Dies Commission launched an investigation of Watson claiming he was a Communist (which Watson always denied) and went on to investigate many other FCC staffers. Brinson reports, "Between 1940 and 1960 FCC commissioners made appearances at minimum of 80 House investigations and 96 Senate investigations, with peak attendance during the $77^{\text {th }}$ Congress $(1940-1941)$ and the $84^{\text {th }}$ through the $86^{\text {th }}$ Congresses (1955-1960)." (Brinson 2004, p. 15) The investigations crippled the FCC's 
ability to regulate, and cost the FCC its leadership as Fly resigned under the strain of ongoing investigations.

The rapid growth of the television industry also strained the FCC because they brought technical issues to the FCC that were ultimately beyond it's ability to fully test or regulate on its very limited budget (Brinson 2004, pp. 12-3). Eventually the FCC was turned it into a tame organization that essentially let the media corporations dictate to it what they wanted in the way of protections for their corporate interests; the FCC operated to protect the industry market, rather than trying to regulate the industry. One generation later, President Clinton signed the Telecommunications Act of 1996, leaving corporations in ownership of all the media, a reversal of FDR's Communications Act of 1934 (which allowed the government to regulate the media industry) and a victory for neoliberal and corporate interests. Viewed through a Weberian analytical lens, the Dies investigations followed by Senator McCarthy's Committee on Un American Affairs both focused on publicly judging whether or not certain individuals were loyal enough Americans. When judged as un American New Deal program employees risked losing their jobs and social standing. The public received a message that New Deal programs were un American because they harbored communists (Brinson, 2004; Storrs 2013). The conservative politicians who lead these commissions were in political parties, which according to Weber reside in the sphere of power and their actions influence social action. In these communist purging investigations, we see party officials exploiting communist threat rhetoric in order to influence social change away from Keynesian or institutional (so-called communistic) style economics and towards neoliberal laissez-faire, utilitarian hedonistic economics.

Although the US won WWII it immediately began an anti-Communist campaign and an arms race with the Soviets, which became the Cold War era. After the Russians launched Sputnik, Congress passed the National Security Act of 1947, which made major changes in the US military structure. It created the Air Force, the Central Intelligence Agency (CIA), a War Council and National Security Council among other changes. This was a legal framework for what President Eisenhower later referred to as, "the military-industrialcomplex" a term suggested to him by physicist Herbert York, former Director of Lawrence Livermore Laboratory (Stone \& Kuznick, 2013, p. 288-9). President Truman signed this legislation into law but worried the CIA would become an uncontrollable, unaccountable, military dictatorship (Stone \& Kuznick, 2013, pp. 212-3) Defense Advanced Research Projects Agency (DARPA) was created to counter "the Communist threat"; its scientists and engineers pioneered development of the hydrogen bomb, the computer and Internet (Norberg \& O'Neill 1996). Here is how Anne Jacobsen, author of The Pentagon's Brain describes DARPA:

. . . the most powerful and most productive military science agency in the world. and one of the most secretive. . . mission to create revolutions in military science. .and maintain technological dominance over the rest of the world . . created by Congress in 1958 . . central research and development organization of the Department of Defense .. annual budget of roughly $\$ 3$ billion .. does not conduct scientific research. Its program managers and directors hire defense contractors, academics, and other government organizations to do the work. DARPA then facilitates the transition of its successful results to the military for 
use. It acts swiftly and with agility, free from standard bureaucracy or red tape. . maintains extraordinarily small staff . . 120 program managers annually, each for roughly five years' tenure. These entrepreneurial leaders are. . .accomplished scientists. . . oversee. . . projects. . involving thousands of scientists and engineers inside national laboratories, military aircraft defense contractor facilities and university laboratories. . . maintain . . . authority in an otherwise rigid military chain of command. . . resulting weapons and weapons related systems are turned over to the Army, Navy, Air Force, and Marines, and to intelligence agencies . . CIA, NSA (National Security Agency), DIA (Defense Intelligence Agency) NGA (National Geospatial-Intelligence Agency), NRO (National Reconnaissance Office) and others, DARPA carefully controls its public persona" (Jacobsen 2015, pp. 5-6).

Now that the US had nuclear weapons, it needed reasons to justify continued funding for weapons development during peacetime. The Communist threat provided reasons when the Soviets exploded their first atomic bomb in 1949. The U.S. responded by dropping the hydrogen bomb "Castle Bravo" in the Marshal Islands in 1954 (Jacobsen 2015 pp.22, 1227). Top-secret weapons development meant guarding against the Communist threat that might steal research secrets. The FBI was ready to help. In 1956 after the McCarthy hearings were censored, Hoover initiated a secret FBI program called COINTELPRO to "disrupt, expose, discredit, and otherwise neutralize the United States Communist party and related organizations" (Churchhill \& Wall 1990 pp. 37-102; Halpern et. al, 1976, p. 112; Stone \& Kuznick, 2013, pp. 235). By 1960 the FBI had secret investigations going on over 430,000 individuals and groups. COINTEPRO was used to inflict a form of punishment for past political actions, without trail (Donner 1981, p. 20). The lawless program terrorized countless citizens and continued for decades, even when it was supposedly stopped in the 1970s (Churchill \& Wall, 1990).

Rand contract economists and scientists exemplify Cold War era occupational statusgroups inside RAND. These economists are the subject of much of Phillip Mirowski's Machine Dreams Economics: Becomes a Cyborg Science (2002). Mirowski unpacks the lives and theoretical work of Cold War era RAND economists and scientists as they pioneered computerized weapons technology designed to enhance human decisionmaking not only for intelligent computers, but for making decisions about nuclear war. Mirowski documents the history of social science being melded to computer technology at a time when only a few social scientists had access to computers. They would be the ones to infuse the programing with neoliberal ways of decision making that could help undermine planned economics and replace it with individual computer terminals. Mirowski explains RAND this way:

RAND was the inspiration for much of the advanced mathematical formalization of the neoclassical orthodoxy in the immediate postwar period. But beyond that, RAND was also the incubator for cyborgs inclined to venture out into the worlds of management, the military, and the social sciences. Systems analysis, artificial intelligence, and the discipline of software engineering all enjoyed their first stirrings there; game theory found its life support system there in those all-too-critical early years. RAND itself was constructed to break down disciplinary barriers between the natural 
and the social sciences and to spread the gospel of complexity (Mirowski, 2002, p. 208).

In the secret research realm of DARPA scientists were using computers for the first time, to: engineer decision making into computer technology, (Norberg \& O'Neill 1996); create neoliberal economic policies and theories to justify continued funding of a national security industry that required constant second guessing about the chances of nuclear holocaust and brinkmanship (Hitch \& McKean 1965); and generating economic theories that hinted at, or anticipated, an information society where choices might be constrained due to consumer ignorance, while government planning is impossible, because the government will never have all the right information, since private companies won't provide it to them (Hayek 1961/2014, p.424).

\section{2 Part Two: The rise of neo-liberalism and the Chicago School}

Post WWII America generated a middle class that for the most part cherished the New Deal programs FDR installed that guarded against the ravages of the Depression and modernized the government's data-banking capabilities (Packard 2018). Keynesian, institutional or government regulation of the economy helped dampen business cycles, avoid depressions, unemployment and inflation (Keynes 1953/1964). Yet by the time President Reagan was serving his second term in office in the 1980s his administration was dismantling much of the government regulations that had benefited his own generation (such as full employment policies, cost of living increases, taxation of the rich, or free college tuition) while Paul Volcker, head of the US Federal Reserve had radically changed monetary policy in ways that undid decades of economic planning and regulation for public welfare (Harvey 2005). F.A. Hayek's, world famous, The Constitution of Liberty (1960) which advocates for individual freedom from planned government economic programs and government cohesion had been a bellwether for neoliberal policies to come; it earned Hayek a Noble Prize and is considered by many to be his greatest work. Prime Minister Thatcher once pulled Hayek's The Constitution of Liberty from her purse to tell Parliament, "We believe in this!" Neoliberalism was in its' heyday during the Reagan years and the policies installed choked New Deal programs, crushed unions, flattened wages and deregulated industries. These developments are the subject of David Harvey's $A$ Brief History of Neoliberalism (2005) in which he explains how powerful leaders like President Ronald Reagan, Prime Minister Margaret Thatcher, Paul Volcker inspired by China's Deng Xiaoping's actions in 1979, to liberalize China's economy, took steps of their own to liberate their economies from government regulations.

But world leaders weren't just reacting to China because conservative resistance to economic ideas focused on labor and production were challenged well before the turn of the century. The Chicago School began in the 1890s; one of its' early economists, Thorstein Veblen authored an article in 1899 titled, "The Preconceptions of Economic Science." It explains how the theory of "normal value" or the economic theory about production force and the labor theory of value posited by Smith and Ricardo (value is part of production force realized in the valuable article) - was challenged by Beuthamism, which posited production is the outcome of a valuation process. Here was hedonistic utilitarianism displacing Smith's idea of normal value, with the a valuation expressed in economic 
conduct, in pursuit of greatest gain or least sacrifice in a market place. Or, the measure of the value of goods accrues from the acquisition of the goods. In this new hedonistic theory individual gain is the substantial end of economic life (Veblen 1899, p. 419) and value is a category of distribution rather than production. In a utilitarian philosophy, society is the sum of the interests of individuals - the sum of the individuals is the gain of society (1899, p. 419). Veblen explains, that this hedonistic utility theory (which today is neo-liberalism) runs on distribution, ownership, acquisition, gain, investment and exchange, whereas Smith's earlier tradition runs on productivity, serviceability and the substantial features of economic life (consider Smith's pin factory, drawn from a material example of productive labor) (Veblen, 1899 p. 418).

What Veblen describes reflects the shift to ideological neoliberal economics doctrine that the Chicago School and its graduates would rationalize. Herman and Julia Schwendinger's book The Sociologists of the Chair examines this shift in the context of American social science between 1883-1922, including Bentham and J.S. Mill's turn-of-century selfinterested, hedonistic utilitarian style economics (1974, p. 439, fn 8). Today the Chicago School and the think tanks to the Pentagon are powerful and persuasive champions of neoliberalism, but Veblen's turn-of-the- century observations about how neoliberalism does and doesn't work are still valid. From high-level government contracted positions, Cold War RAND neoliberal economists, advantaged with early computers and programing capabilities, performed applied neoliberal economic doctrine (Harvey, 2005) by protecting and creating markets for DARPA's products and creating new markets for weapons - or weapons for new markets as Mirowski (2002), Levine (2018), Edwards (1996), Singer (2009) and Zuboff (2019) describe. Chicago School economists, backed by Rockefeller and validated by record breaking numbers of Noble Prizes for Economics and other rewards (at least nine Noble Prizes for Economics have gone to Chicago School economists) revolutionized how business is done around the world by shifting economic priorities away from social concerns about labor and unemployment (a driving concern behind the New Deal and Keynesian economics) over to concern for unregulated markets, price theory and dismantling the International Monetary Fund and Bretton Woods system (Leeson, 2003, 2008). Mirowski sums up the "three commandments" of Chicago School style, neo-liberal economics this way:

Its first commandment is that the market always "works." in the sense that its unimpeded operation maximizes welfare. Its second commandment is that the government is always part of the problem, rather than the solution. The third commandment is that the demand curve is the rock-bottom fundamental entity in price theory, and that attempts to "go behind" the demand curve in order to locate its foundations in the laws of utility or "indifference" . . . were primarily a waste of time and effort (Mirowski 2002, p.203-4).

The Chicago School economics, sometimes dubbed "counter-revolutionary" theory (Leeson 2000) usurped so-called socialist or Marxian and Keynesian theories with ideas about prices as the best way to interact in an information-mediated market; bypassing theoretical and real concerns about labor, the worker, the capitalist and people as agents of change. Chicago School economists helped install free-market oriented economic policies in Chile after the CIA coup that murdered President Allende (Hammond 2011). 
Although Neoliberal economists saw government as the problem, ironically politicians like Reagan and Thatcher saw the Chicago School's premier economists Hayek and Milton Friedman, as experts who sent the right proprietary message to government policy makers; that neoliberal policy should be supported in part because noble prize winning economists advocated it. Hayek was stanchly opposed to government regulation and took a Noble Prize for his theoretical work pertaining to the "communication function of the market". On the one hand, neoliberal policies delivered benefits to some, for example Rockefeller's Cold War era subsidies to the Chicago School delivered rewarding returns to neoliberal corporate banking interests following the sub-prime mortgage crisis of 2009. On the other hand, Rohde describes the experience of military contracted social scientists in the Special Operations Research Office (SORO) as conflicted. Many people didn't view the new neoliberal-ized contract-government and military intelligence service, as a statusoccupation but as a downgrade of the government. Rohde wrote:

It seemed to critics that the Pentagon was destroying the democracy it was suppose to protect. By outsourcing vital intellectual expertise and paying a premium for it, the government seemed to be eroding its own intellectual capacity, crippling the public sector. Furthermore, both the public and the government seemed to lack the oversight capabilities necessary to manage the contract state (Rohde, 2013, pp. 2-3).

3.3 Part Three: case study of the FBI protecting against the so-called communist threat at University of California, Berkeley during the Cold War years,

President of University of California at Berkeley, Clark Kerr, sent his "Master Plan for Higher Education" to the state legislator on February 1, 1960; this plan would set the standard for universities around the world (Rosenfeld, 2013, p. 76). In the early 1960s Hoover ordered a search of the FBI's "Security Index" files of the 6,000 faculty members of the University of California and filed a report titled, "What is the University of California?" which depicted the university as something akin to a military counterinsurgency target (Rosenfeld 2013, p 70). Also in the 1960s RAND added a large counterinsurgency division and became an extension of ARPA's Project Agile (in Vietnam) together with Command and Control (in Cambridge Mass.), which together, would manifest in the Internet; ARPA placed the orders; RAND hired the people and got the job done (Levine 2019, p. 29).

eth Rosenfeld's Subversives: The FBl's War on Student Radicals and Reagan's Rise to Power (2013) is an account of the history behind the student lead free speech movements at University of California at Berkeley (UCB) in the 1960s. These events lead Governor Ronald Reagan to call in the National Guard to end student actions on the UC campus, resulting in violence that shocked the nation. Regan had fired the president of UCB Clark Kerr, who was replaced by Charles Hitch, a co-author of The Economics of Defense in the Nuclear Age (1965) which introduced Americans to the idea of national security, an annual Pentagon budget tied to a percentage of GNP and the idea of endless nuclear war preparations. 
Reagan went go on to win the Presidency for two terms in the 1980s during which time neoliberal economic policies were considered to be at their apex - with the Internet privatized, without public debate or even much public knowledge of it. Here is a case in which the various actors, ideologies and rational discussed above, interact in a dramatic way which appears, on the surface, to be about the student free speech movements. However, thanks to Rosenfeld's findings in Freedom of Information Act (FOIA) documents, the events also had to do with the FBI protecting the UCB labs and DARPA budgets from being administered by someone who the FBI thought was a communist threat, namely President Clark Kerr (Rosenfeld 2013, 490-502). Here is a vivid example of the militaryindustrial-complex constellation of intelligence agents and political classes at work controlling part of the monopoly complex's market system, namely the University of California at Berkeley, Berkeley Radiation Lab.

The FBI had recruited Ronald Reagan in 1946 to be an informant in Hollywood, when FBI Director J. Edgar Hoover put operation COMPIC (Communist Infiltration of the Motion Picture Industry) into action. Hoover and Regan helped each other. Regan informed on Communists in Hollywood, who were then blacklisted and Hoover helped Regan become President. Part of this quid pro quo process entailed ousting Clark Kerr from the President's position at UCB (Rosenfeld 2013, pp. 372-80, 507). J. Edgar Hoover was convinced the UCB Radiation labs were infiltrated with communists. He based this on information from Hugh M Burns, Chair of State Senate Fact Finding Committee on Un American Activities. Hoover launched an investigation into UCB at a time when friction was occurring within the circles of the world's premier bomb engineers. Oppenheimer, who was at UCB, had built the atomic bomb - but then he advocated against development of hydrogen bombs. This put him at odds with Edward Teller who created the hydrogen bomb under the DARPA program. Oppenheimer's security clearance was revoked (Rosenfeld, 2013, p. 26). Teller on the other hand enjoyed the privileges of his occupational-status group without being censored. The FBI was concerned that Oppenheimer was leaking nuclear secrets and opened up CINRAD (Communist Infiltration of the Radiation Laboratory) after which it was busy doing illegal break ins, wiretapping and spying on the UCB community.

J. Edgar Hoover had other reasons for targeting Kerr; reasons having to do with Hoover's ideology about Americanism. Hoover began his career by raiding and purging mostly poor immigrants from the US, including Emma Goldman. (Rosenfeld, 2013, p. 17). In 1951 Hoover started a secret nationwide loyalty program to purge politically suspect teachers called the "Responsibilities Program." The program enabled firing teachers for reasons that they could not get evidence for and could not confront their accusers about. Teachers could be fired just because their name appeared on a list that the FBI had given to school authorities. The entire program was kept a secret until leaks about it threatened the FBI's credibility - then the program was stopped. This operation exemplified Hoover's modus operandi. Donner's Age of Surveillance: The Aims and Methods of America's Intelligence System explains much of the anti-communist ideology that permeated the FBI to justify operations and funding. Donner profiles Hoover as essentially lawless or operating with impunity while gathering information on everyone, using spies, wiretaps, recordings and photos that were banked and used against people. Hoover built up a very famous card index file on people similar to the card index the Nazi's used (Aly \& Roth, 2004, p. 3; Stone \& Kuznick 2013, p35). Donner writes, "no government official has communicated to a 
national audience in such volume as J.E. Hoover". Ghostwriters authored hundreds of Hoovers books, articles, pamphlets, and speeches. The FBI provided production equipment for movies and TV and radio broadcasts to make programs to boost the image of the $\mathrm{FBI}$ and promote Americanism (Donner 1981, p. 467-77).

In contrast, Clark Kerr began his career as a student of economic planning at UCB during the depression. He studied under Paul Taylor an expert in farm labor who married Dorthea Lange, whose photographs of impoverished Dust Bowl farmworkers in the Great Depression are world famous. Clark Kerr had been raised on a farm in Pennsylvania and had become a Quaker. Taylor sent Kerr to report on people involved in the San Joaquin cotton picker's strike of 1933. It was the biggest and most bloody agricultural strike in the US. Agricultural interests were concerned that Taylor was meddling in their business and they complained to UCB. It was this strike that prompted the communication to Hoover about communists at UCB, from Hugh M Burns. Kerr was probably under surveillance by the FBI even when he was a student. Kerr took a job with the California Emergency Relief Administration, a New Deal program, helping to develop farm co-ops. He became a labor arbitrator and professor at University of Washington. He became first Chancellor of Berkeley (1952-1958). He was President of the UC system from 1958 to 1967. He was the author of the 1960 Master Plan, the blueprint for the University of California system, which set the standard for higher education institutions around the world. His book The Uses of the University (1963) is one of the most influential books on modern research universities. It describes the university as a "multiversity" and devotes a chapter to "The Realities of the Federal Grant University" where he explains how federal funding for scientific research after WWII has impacted universities writing, 'Don K. Price notes that "in the hands of Vannevar Bush, James B. Conant, and Karl T. Compton the government contract became a new type of federalism.' (Kerr 1963, p. 48). After that he gives some figures about where the federal funds are allotted and comments that once the university was for training gentlemen but now it is in the service of "brute technology" (Kerr 1963 p 49). He discusses how federal influence has usurped the university of it's professionals who are under the pressure of "agency contracts" causing them to shift their identification and loyalty from their university to the agency in Washington. Thus the federal research funds undermine the university by turning it into a "hotel" for temporary contracted researchers. Of this process Kerr observes: "The agency becomes the new alma mater. The research entrepreneur becomes a euphoric schizophrenic" (Kerr 1963, p. 59). Kerr goes on to advocate for funding educational programs that are not science research oriented. Kerr also authored Marshall, Marx and Modern Times: The Multi-dimensional Society (1969) where he compares two economists Marshal and Marx and discusses modern society in terms of pluralism and a society of integrated organizations that are run not by the fist of revolution or the invisible hand of the market but by the "hidden hand of the experts in the offices of government agencies" (Kerr, 1969, p. 89) By all accounts Kerr is praised for his professionalism, fairness, excellent arbitration skills, popularity and masterful achievements as the architect of the UC system (González, 2011; Kerr 1963; Marginson 2016; Rosenfeld, 2013).

These contrasting occupational-status-group accounts of Hoover and Kerr point up the differences between Hoover's secretive illegal operations and public 100 percent American 
and anti-communist ideology, that protects neoliberal business, the federal government and market interests and Kerr's social welfare and university planning approach - and go a long way in explaining why Kerr was deemed a communist by Hoover and stripped of his status group occupation. Not only did Kerr publish information about federal research funding, he was critical of them. This breaks with the code of honor of the occupation status group because the market is suppose to be protected not discussed critically in publications. Kerr refused to set the right proprietary example to the public about how to think about national defense - and the complex replaced him with Charles Hitch, who had helped write the funding plan for the military-industrial-complex in The Economics of Defense in the Nuclear Age (1965). This brief comparison of Hoover and Kerr is only the beginning of a long saga of similar history that transpires over decades. The constellations of status groups, party interests, and class members intersecting in the military-industrialcomplex, show themselves in this case study, kept secret in files that the FBI spent more than a million dollars to try to withhold from Rosenfeld (Rosenfeld, 2013, pp. 505-12).

\section{Conclusion}

When the Internet became a viable tool for commercialization by the 1980 s it was probably important to the military-industrial-complex to have a neoliberal President in office to help make privatizing the Internet easier. The FBI helped smooth the path to Internet privatization by sacrificing Kerr and handing UCB over to a RAND man who would help deflect possible student or faculty protests regarding military research on campus. During the creation of "People's Park" in Berkeley Reagan, who had endlessly claimed that protestors were the enemy and threatened national security, sent in the National Guard to suppress Berkeley protestors. Police were authorized to use riot guns. They shot buckshot into protestors, killing one and blinding another. Tear gas was dropped on campus. People were penned in by armed police and hauled off to Santa Rita County Jail and Prison. This day made history in Berkeley; never had there been so much violence against protestors (Rosenfeld, 2013, pp. 440-87). Today UC Berkeley keeps pictures of these protest events in the UCB student union, while up the road, UC Davis (the agricultural campus) keeps photos by Dorthea Lange and other historical photos of impoverished rural American farmers on display throughout the Shield's library, a mute tribute to Kerr's legacy and dream and to students who believe in free speech. However the violence didn't bother Regan and in fact his popularity soared (Rosenfeld 2013, p. 446); he was sending the right proprietary message to the public that he, unlike Kerr, would not tolerate protests (and presumably that would have included any future protests about privatization of the Internet, too). Once elected President, Reagan, as a member of a party, allowed National Science Foundation status-group members to distribute the taxpayer-paid-for-Internet-infrastructure to specific private companies. They were doing their jobs according to neoliberal doctrine. Since government was the problem it was their job to create the right market for the Internet, while controlling the monopoly on it until delivery.

Levine reports on how Stephen Wolff helped privatized the Internet. Essentially the National Science Foundation (NSF), as an educational program, had a special "Net backbone" infrastructure built for academic purposes, which it allowed IBM and $\mathrm{MCI}$ to use 
for private business purposes, without letting either the public or other market competitors know about the deal. Levin writes:

In short, the NSF directly subsidized the MCI-IBM consortium's national business expansion. The company used its privileged position to attract commercial clients, telling them that its service was better and faster because it had direct access to the national high-speed backbone. Stephen Wolff understood that backing a telecommunications company like $\mathrm{MCl}$ could lead to a situation where a handful of powerful corporations controlled the newly created Internet, but he brushed those dangers aside. As Wolff explained in an interview at the time, his main objective was to bring a viable commercial Internet into existence. Regulating fairness and competitive practices was someone else's job. On a very basic level, he was right. The problem was that by building a privatized network, he was also building an industry and by extension, laying down the basic rules that governed and regulated this industry. These were intertwined. (Levine, 2018, p. 123)

Levine goes on to explain how "Wolff's laissez-fair management style" fell under fire since it gave unfair market advantage to some networking companies but not others; not because it short changed taxpayers who had paid for the technology already and now were going to pay to use it, at commercial rates, which would bring huge profits to tele-com owners and shareholders, who hadn't had to pay for the infrastructure. Today six of the richest people in the world, Bill Gates, Carlos Slim Helu, Jeff Bezos, Mark Zuckerman, Larry Ellison, and Warren Buffet reap profits from telecommunication companies (Matthews 2019; Phillips 2018) owe their technological origination to taxpayer paid-for-research conducted in government regulated Operations and Research military programs. The Internet, born from government-regulated research and paid for by the public, was privatized in the midst of Ronald Reagan's tenure as President, a time when everything was being de-regulated, privatized and subject to neo-liberal designs. Again Levine:

The Internet is perhaps one of the most valuable public inventions of the twentieth century, and decisions made by a few key unelected officials in the federal bureaucracy set the Internet on the certain path to privatization. There was no real debate, no discussion, and no oversight. It was just given away, before anyone outside the bureaucratic bubble realized what was at stake (2018, p. 120-1).

The communist threat and neoliberal doctrine provided a rational for occupationalspecially-skilled, computer assisted, status group contact scientists in DARPA or RAND to help control and protect their weapons and Internet markets by discrimination, monopoly and anti-communist purging campaigns. The Communist threat served a duo purpose, like a carrot it incentivized military-industrial-complex funding of Internet and weapons research (at the expense of social funding) and like a stick, it enabled neutralizing so-called Communists, who might challenge privatization of the Internet (or other weapons). During the Cold War era in the US, many talented, hardworking, skilled Americans particularly academics, anti-war, American Indian Movement, Black Panthers and women's groups 
were spied on, investigated and smeared in public, purged from their jobs and ostracized, and sometimes murdered or maimed, because of being secretly deemed "un-American" by intelligence agents, by conservative interests or peer pressure. The Communist threat abroad justified increased funding for national security and DARPA programs. In seeking market territory in North Atlantic Treaty Organization (NATO) countries, during the Cold War, it was important for the US to appear to have strong anti-communist sentiments, which justified domestic anti-communist purges and COINTELPRO operations.

Military and DARPA scientists pioneered the merger of social science with computerized programing, which they engineered for individual consumers with a neoliberal orientation, rather than a socialized approach to either decision-making or utility ownership and use. In 1972, a decade before the Internet was privatized, Defense Advanced Research Projects Agency (DARPA) scientists/engineers who engineered the proto-Internet, the ARPANET, helped the $\mathrm{FBI}$ and the Pentagon spy on people by using the ARPANET to transfer surveillance files on so-called communists (war protestors) to the Pentagon and other parts of the military-industrial-complex. (Levine 2018, p. 187). This historical fact shows, 1) Internet technology was used against so-called communists who might ideologically have advocated for public debate regarding privatization of the Internet (Donner 1981; p. Halpern et al. 1976); 2) It shows DARPA contractors had a monopoly on computer technology at that time (Weber 1978, p 937; Mirowski, 2002;Norberg \& O'Neill 1996); 3) that surveillance technology was incentivized by the so-called communist threat, which incentivized funding for more spying technology (Levine, 2018) ; 4) the computer technology made to meet that demand, was created by self-styled specially-skilled-occupation-status-group of scientists who weren't bureaucrats or intelligence agents or military personnel but rather contracted civilians (Levine, 2018; Mirowski 2002; Norberg \& O’Neil 1996, pp. 1,8,25,26,28,31,50; Weber 1978, pp. 306-7, 937) who ; 5) assisted in releasing the Internet into a selected private market - in accordance with anti-communist, neoliberal and skilled-occupationalstatus group allegiances (Levine Weber 1978, p 937). The technology these scientists created, the Internet, once privatized and commercialized, helped to further marginalize social welfare and government planning economics while increasing neoliberal selfinterested economics (branding, algorithms, etc.)

From the turn of the century to 1980s the combined efforts of: un American activity investigations and the purging of suspected Communists from government positions; neoliberal and conservative business efforts to undermine New Deal programs while funding a new military-industrial-complex; along with intelligence agencies' secret spying and illegal intrusive activity into the lives of anti-war and civil rights activists, all reduced the possibility of a public uprising to demand government regulation of the Internet. Scott Horton's Lords of Secrecy: the National Security Elite and America's Stealth Warfare describes the contemporary version of todays' secret group of self-directed, weapons manufacturing companies and agents who wage endless wars across the world with guaranteed tax dollars and impunity. "Horton makes an observation that sounds similar to Kerr's observation about the "hidden expert hand" that might be exemplified by former Secretary of State Donald Rumsfeld in "The Unknown Known" (Packard 2019). Horton writes:

In the period following World War II and rapidly accelerating in the new millennium, the proliferation of secrecy has acted as a gate 
mechanism. It has moved ever more subjects off the public stage, ensuring that these issues are managed not through democratic discussion but through a bureaucratic-technical decision-making system (Horton 2015, p. 96).

Using Weber's theoretical status group model, an argument is made that the militaryindustrial-elite and their literati style neoliberal Noble Prize winning economists made a powerful status group against, out-numbered institutional or Keynesian and New Deal advocates, like Clark Kerr, President of the University of California, or Larry Fly, the first Chairman of the Federal Communications Commission; an inequality mirrored in the rise of the computer and Internet assisted popularity and prestige of neoliberalism economic policy throughout the post WWII decades and throughout the world (Morgan \& Rutherford, 1998) .

The neoliberal ideal of the free market, where the businessman runs his own business without government coercion, (Hayek 1960/2011) seems a bit hypocritical when juxtaposed next to a military-industrial-complex subsidized by taxpayers for un-measurable national security and administered by occupational-status-group-contract employees entrusted to control the marketing of products of that complex. The FBI had to show numbers for its' funding but enjoyed autonomy, while the military-industrial-complex enjoyed secured funding and autonomy. Neoliberal economics negates the factor of productivity, leaving its' rational and theory open to application to a slave or a robotics society. Weber ascribes slaves to status groups because their fate doesn't rely on using or owning the goods and services they may be producing (Weber 1978, p. 928). In other words, the contractedstatus-group scientists, engineers and technicians who built the Internet did not own it.

The cumulative events of the Red Scare, Cold War, the anti-war protests and the intelligence agencies backlash against those protests, along with the rise of neoliberal economic policies that choked New Deal programs, crushed unions, flattened wages and deregulated industries, altogether helped pacify and neutralize the American public, clearing a less resistant path for privatization of the Internet. In the case of the Internet, the FBI helped DARPA test-drive the Internet by transferring COINTELPRO files on thousands of people from the FBI to the Pentagon via the ARPANET. And DARPA made privatization easier by withholding information about the Internet; so people who might question its' privatization didn't have enough information to challenge the government. Both the FBI and DARPA used neoliberal, anti-communist and national security rhetoric or ideology to justify their actions and to protect and control markets and secrets from so-called communist subversion, infiltration or theft. There is also a moral dimension to neoliberalism which dictates individuals are responsible for their own betterment. Those who don't abide by the norms or protest against them and refuse to support them are not worthy of being included in the information loop or having access to a better life. This is discussed in Appendix D "Alienation, Dropouts, and the Claims of Parasites" of F.A. Hayek's The Fatal Conceit: The Errors of Socialism written in 1968, at the height of the anti-war, civil rights era (1968, Hayek, p. 152-3).

The Free Speech movement at University of California, Berkeley, in 1969, saw all the people discussed above (military, intelligence, university, protesters and neoliberal) coalesce and collide violently over claims of communist infiltration on campus. These 
events were used to pad the numbers of supposed communists, to increase funding for FBI spy operations and surveillance and internet technology and to help elect President Ronald Reagan, whose neoliberal administration oversaw the speedy and uncontested privatization and commercialization of the Internet. Those who protested about tax money spent on war might also have protested against the Internet being privatized, so there was an incentive to spy on anti-war protestors, while keeping national security secrets about weapons and Internet development ever more contained.

By the time President Reagan's administration privatized the Internet in the late 1980s much of the US population was still rebounding from years of division and protest over the horrific Vietnam War. When the US pulled out of Vietnam many people were not eager to be protesting again; particularly over something as mysterious and mis-understood as the Internet, that was touted as a new technology that would make everything easier, faster and more convenient. Compared to news coverage about the Vietnam War, coverage about the Internet seemed minuscule, so mobilizing to nationalize or regulate this mysterious "thing" was simply un-thought of. Unlike Vietnam, which was in the public eye for the whole world to see, people were alienated (in a very Marxian sense) from any relationship or sense of control over what their tax money had produced in the hidden, secreted, out-of-sight and out-of-mind, Internet. Little wonder the Internet was privatized without public descent, the public was ill-informed about it and up against the secret but well-informed, powerful interests of a neoliberal inspired military-industrial-complex, which worked for years implementing what would become a whole new mode of production and exchange. Part of that work included pacifying so-called communists who might challenge Internet privatization and another part of the work was selling the virtues of neoliberal ideology to the world - a goal made easier with a globalized, privatized, Internet.

\section{ACKNOWLEDGEMENTS:}

Thank you to University of Auckland for travel funding to attend the IISES $5^{\text {th }}$ Arts and Humanities Conference, Copenhagen, June 24-7, 2019 and the IISES International Academic Conference, Prague June 17- 20, 2019. Thank you to Professor Neal Curtis of the Media, Film \& Television Department at University of Auckland, for commenting on drafts and to the University of Auckland's Library staff for help with inter-loan requests.

\section{REFERENCES}

ALY, G \& ROTH, K.H. (2004). The Nazi Census: Identification and control in the Third Reich. Philadelphia, Penn: Temple University Press.

BRINSON, S (2004). The Red Scare, Politics, and the Federal Communications Commission, 1941-1960. Westport, Conn: PRAEGER.

CHURCHILL W. \& VANDER WALL J. (1990). Agents of Repression: The FBl's Secret Wars Against the Black Panther Party and the American Indian Movement

DONNER, F. J. (1981) The Age of Surveillance: The aims and methods of America's political Intelligence system. New York: Vintage Books

EDWARDS, P.N. (1996). The Closed World: Computers and the Politics of Discourse in Cold War America. Cambridge, Mass.: The MIT Press. 
GONZÁLEZ, C. (2011). Clark Kerr's University of California: Leadership, Diversity and Planning in Higher Education. New Brunswick, N.J: Transaction Press

HALPERIN, M. H., BERMAN, J.J., BOROSAGE, R.L. \& MARWICK, C.M. (1976). The Lawless State: The Crimes of the U.S. Intelligence Agencies. Penguin Books.

HAMMOND, D.J. (2011). Markets, Politics, and Democracy at Chicago: Taking Economics Seriously. In Building Chicago Economics: New Perspectives on the History of America's Most Powerful Economics Program (Eds. Van Horn, R., Mirowski, P., Stapleford, T. A.) (pp. 36-66) New York, N.Y.: Cambridge University Press.

HARVEY, D. (2005). A Brief History of Neoliberalism. New York, N.Y.: Oxford University Press.

HAYEK, F.A. (1961/2014). A New Look at Economic Theory-Four Lectures Given at the University of Virginia, 1961: Lecture IV. The Communication Function of the Market in The Market and Other Orders (Ed. Caldwell, B.) Volume 15 (pp. 415-427). Chicago, II: The University of Chicago Press

HAYEK, F.A. (1960/2011). The Constitution of Liberty: The Definitive Edition in The Collected Works of F.A. Hayek (Vol XVII). (Ed.) Hamony, R. Chicago, II.: University of Chicago Press.

HITCH, C. J. \& McKEAN, R.N. (1965) The Economics of Defense in the Nuclear Age. With contributions from, Enke, S., Enthoven, A., Hoag, M., McGuire, C.B., and Wohlstetter, A. New York, N.Y.: Atheneum.

HORTON, S. (2015) Lords of Secrecy: The National Security Elite and America's Stealth Warfare. New York N.Y.: Nation Books.

JACOBSEN, A. (2015). The Pentagon's Brain; An Uncensored History of DARPA America's Top Secret Military Research Agency. New York, N.Y.: Black Bay Books.

KERR, C. (1969). Marshall, Marx and Modern Times. London, Cambridge: Cambridge University Press.

KERR, C. (1963). The Uses of the University. Cambridge, Mass.: Harvard University Press.

KEYNES, J.M. (1964/1953). The General Theory of Employment, Interest and Money. New York N.Y.: Harcourt Inc.

LEESON, R. (Ed.) (2008). The Anti-Keynesian Tradition. Great Britain: Palgrave

LEESON, R. (2003). Ideology and the International Economy: the Decline and Fall of Bretton Woods. NY, NY: Palgrave MacMillan.

LEESON, R. (2000). The Eclipse of Keynesianism: The Political Economy of the Chicago CounterRevolution. Great Britain: Palgrave

LEVINE, Y. (2018). Surveillance Valley: The Secret Military History of the Internet. New York, N.Y: Public Affairs.

MARGINSON S. (2016). The Dream is Over: The Crisis of Clark Kerr's California Idea of Higher Education. Oakland, CA.: University of California Press. DOI: http://doi. Org/10.1525/luminous.17 Retrieved from University of Auckland library 11 February, 2019.

MATTHEWS, D. (2019). "Are 26 billionaires worth more than half the planet? The debate, explained." January 22, 2019. https://www.vox.com/future-perfect/2019/1/22/18192774/oxfam-inequality-report-2019davos-wealth. 
MIROWSKI, P. (2002). Machine Dreams: Economics Becomes a Cyborg Science. N.Y., N.Y.: Cambridge University Press.

MORGAN, M.S. \& RUTHERFORD, M. (Eds.) (1998). From Interwar Pluralism to Postwar Neoclassicism. Annual Supplement to Volume 30 History of Political Economy. Durham NC: Duke University Press.

MURRAY, R. K. (1955). Red Scare: A Study in National Hysteria, 1919-1920. St. Paul Minn: University of Minnesota Press.

NORBERG, A. L. \& O'Neill J.E. (1996) Transforming Computer Technology Information Processing for the Pentagon, 1962-1986. Baltimore MD: John Hopkins University Press.

PHILLIPS, P. (2018). GIANTS: The Global Power Elite. Oakland, CA: Seven Stories Press.

PACKARD, N. (2019, June) Alienating Marx(ists) From the Cold War into Surveillance Capitalism. Preliminary Proceedings of the 47th International Academic Conference, of International Institute of Social and Economic Sciences, Prague, Czech Republic. https://www.iises.net/proceedings/iises-international-academic-conference-prague/table-ofcontent/detail?article=alienating-marx-ists-from-the-cold-war-into-surveillance-capitalism

PACKARD, N. (2018) Statistical demand-pull in 1930's U.S.A and Germany: Good will, Welfare and Warfare. In Cogent Social Sciences, 4, 1, (pp. 1-20), DOI: 10.1080/23311886.2018.1531737.

RAUCHWAY, E. (2018). Winter War: Hoover, Roosevelt, and the First Clash Over the New Deal. New York, N.Y: Basic Books.

ROHDE, J. (2013). Armed with Expertise: The Militarization of American Social Research During the Cold War. Cornell, N.Y.: Cornell University Press.

ROSENFELD, S. (2013) Subversives: The FBl's War on student radicals and Reagan's rise to power. New York: Farrar, Straus, and Giroux.

SCHWENDINGER H. \& SCHWENDINGER J. (1974). The Sociologists of the Chair: A Radical Analysis of the Formative Years of North American Sociology (1883-1922). New York, N.Y.: Basic Books

SINGER, P.W. (2009) Wired for War: The Robotics Revolution and Conflict in the $21^{\text {st }}$ Century. New York, N.Y: Penguin Press

STONE, O. \& KUZNICK, P. (2013) The Untold History of the United States. US: Ebury.

STORRS, L. R. (2013). The Second Red Scare and the Unmaking of the New Deal Left. Princeton N.J.: Princeton University Press.

THEOHARIS, A. (summer, 1985). The FBI and the American Legion Contact Program, 1940-1966. Political Science Quarterly, (100) 2, pp. $271-286$.

VAN HORN, R., MIROWSKI, P. , STAPELFORD, T. A. (Eds.) (2011). Building Chicago Economics: New Perspectives on the History of America's Most Powerful Economics Program. New York, N.Y.: Cambridge University Press.

VAN OVERTVELDT, J. (2007). The Chicago School: How the University of Chicago Assembled the Thinkers Who Revolutionized Economics and Business. Chicago, II: B2

VEBLEN, T. (Jul, 1899). The Preconceptions of Economic Science in The Quarterly Journal of Economics, pp.396-426. Retrieved 11 Feb, 2019 from https;//www.jstor.org/stable/1883645 
WEBER, M. (1930/1992) The Protestant Ethic and the Spirit of Capitalism. New York N.Y: Routledge

WEBER, M. (1978). Economy and Society. Edited by G. Roth and C. Wittich. Translated By E. Fischoff, H. Gerth, A.M. Henderson, F. Kolegar, C. W. Mills, T. Parsons, M. Rheinstein, G. Roth, E. Shils, C. Wittich. Berkeley: University of California Press.

WEBER, M. (1951/1964). "The Literati." in The Religion of China. Translated and edited by pp.107-41 H. H. Gerth. New York: Macmillan.

ZUBOFF S. (2019). The Age of Surveillance Capitalism: the Fight for a Human Future at the New Frontier of Power. USA: Profile Books 